\title{
Front Matter: Volume 10227
}

, "Front Matter: Volume 10227," Proc. SPIE 10227, Metamaterials XI, 1022701 (15 June 2017); doi: 10.1117/12.2281958

SPIE. Event: SPIE Optics + Optoelectronics, 2017, Prague, Czech Republic 


\title{
PROCEEDINGS OF SPIE
}

\section{Metamaterials XI}

\author{
Vladimír Kuzmiak \\ Peter Markos \\ Tomasz Szoplik \\ Editors
}

\section{6-27 April 2017 \\ Prague, Czech Republic}

Sponsored by

SPIE

Cooperating Organisations

Science and Technology Facilities Council (United Kingdom)

ELI Beamlines (Czech Republic)

Laserlab Europe

AlLU_Association of Laser Users (United Kingdom)

European Optical Society

HiLASE (Czech Republic)

AWE-Atomic Weapons Establishment (United Kingdom)

Published by

SPIE 
The papers in this volume were part of the technical conference cited on the cover and title page. Papers were selected and subject to review by the editors and conference program committee. Some conference presentations may not be available for publication. Additional papers and presentation recordings may be available online in the SPIE Digital Library at SPIEDigitallibrary.org.

The papers reflect the work and thoughts of the authors and are published herein as submitted. The publisher is not responsible for the validity of the information or for any outcomes resulting from reliance thereon.

Please use the following format to cite material from these proceedings:

Author(s), "Title of Paper," in Metamaterials XI, edited by Vladimír Kuzmiak, Peter Markos, Tomasz Szoplik, Proceedings of SPIE Vol. 10227 (SPIE, Bellingham, WA, 2017) Article CID Number.

ISSN: 0277-786X

ISSN: 1996-756X (electronic)

ISBN: 9781510609556

ISBN: 9781510609563 (electronic)

Published by

SPIE

P.O. Box 10, Bellingham, Washington 98227-0010 USA

Telephone +1 3606763290 (Pacific Time) · Fax +1 3606471445

SPIE.org

Copyright @ 2017 , Society of Photo-Optical Instrumentation Engineers.

Copying of material in this book for internal or personal use, or for the internal or personal use of specific clients, beyond the fair use provisions granted by the U.S. Copyright Law is authorized by SPIE subject to payment of copying fees. The Transactional Reporting Service base fee for this volume is $\$ 18.00$ per article (or portion thereof), which should be paid directly to the Copyright Clearance Center (CCC), 222 Rosewood Drive, Danvers, MA 01923 . Payment may also be made electronically through CCC Online at copyright.com. Other copying for republication, resale, advertising or promotion, or any form of systematic or multiple reproduction of any material in this book is prohibited except with permission in writing from the publisher. The CCC fee code is $0277-786 \mathrm{X} / 17 / \$ 18.00$.

Printed in the United States of America.

Publication of record for individual papers is online in the SPIE Digital Library.

\section{SPIE. DIGITAL}

Paper Numbering: Proceedings of SPIE follow an e-First publication model. A unique citation identifier (CID) number is assigned to each article at the time of publication. Utilization of CIDs allows articles to be fully citable as soon as they are published online, and connects the same identifier to all online and print versions of the publication. SPIE uses a seven-digit CID article numbering system structured as follows:

- The five digits correspond to the SPIE volume number.

- The last two digits indicate publication order within the volume using a Base 36 numbering system employing both numerals and letters. These two-number sets start with 00, 01, 02, 03, 04, 05, 06, 07, 08, 09, OA, OB ... 0Z, followed by 10-1Z, 20-2Z, etc. The CID Number appears on each page of the manuscript. 


\title{
Contents
}

\author{
$\checkmark$ Authors \\ vii Conference Committee
}

\section{METASURFACES}

1022703 Tunable spin-directional coupling for surface localized waves with anisotropic metasurface (Best Student Paper) [10227-2]

\section{METAMATERIALS THEORY}

1022709 On-chip near-wavelength diffraction gratings for surface electromagnetic waves [10227-8]

10227 OA On-chip phase-shifted Bragg gratings and their application for spatiotemporal transformation of Bloch surface waves [10227-9]

$10227 \mathrm{OB}$ Enhanced fluorescence emission using bound states in continuum in a photonic crystal membrane [10227-10]

HYPERBOLIC METAMATERIALS

10227 OG Quasimode computation in structures including several dispersive materials [10227-15]

$10227 \mathrm{OH}$ Spectral features of the Borrmann effect in 1D photonic crystals in the Lave geometry [10227-16]

\section{PLASMONICS}

1022700 Collective dynamics of atoms embedded into negative index materials [10227-23]

10227 OR General rules for incorporating noble metal nanoparticles in organic solar cells [10227-26]

NANOLASERS

10227 OV Plasma phase separation in bismuth and antimony chalcogenide crystals [10227-30] 
10227 OZ Deposition of organic molecules on gold nanoantennas for sensing [10227-34]

\section{POSTER SESSION}

1022712 Plasmonic scattering nanostructures for efficient light trapping in flat CZTS solar cells [10227-36] 


\section{Authors}

Numbers in the index correspond to the last two digits of the seven-digit citation identifier (CID) article numbering system used in Proceedings of SPIE. The first five digits reflect the volume number. Base 36 numbering is employed for the last two digits and indicates the order of articles within the volume. Numbers start with 00, 01, 02, 03, 04, 05, 06, 07, 08, 09, OA, OB...0Z, followed by 10-1Z, 20-2Z, etc.

Abdelrahaman, M. Ismail, 12

Abdelraouf, Omar A. M., 12

Allam, Nageh K., 12

Bezus, Evgeni A., 09, 0A

Bliokh, Konstantin Y., 03

Bogdanov, Andrey A., 03

Bykov, Dmitry A., OA

Cabrini, S., OB

Ciesielski, A., OR

De La Rue, Richard M., OZ

De Luca, A. C., OB

Demésy, Guillaume, OG

Dhuey, S., OB

Doskolovich, Leonid L., 09, 0A

Ficek, Zbigniew, 00

Garcia-Vergara, Mauricio, OG

Golovastikov, Nikita V., OA

Iorsh, Ivan V., 03

Johnson, Nigel P., OZ

Kivshar, Yuri S., 03

Li, Gao-xiang, $0 \mathrm{O}$

Managò, S., OB

Mantsyzov, B. I., $\mathrm{OH}$

McMeekin, Scott G., OZ

Mocella, V., OB

Morozov, Andrey A., 09

Murzina, T. V., $\mathrm{OH}$

Netesova, Nadezhda P., OV

Nicolet, André, OG

Novikov, V. B., $\mathrm{OH}$

Paul, Jharna, $\mathrm{OZ}$

Penzo, E., OB

Podlipnov, Vladimir V., 09

Romano, S., OB

Switlik, D., OR

Szoplik, T., OR

Wei, Fang, 00

Yermakov, Oleh Y., 03

Zito, G., OB

Zolla, Frédéric, OG 
Proc. of SPIE Vol. 10227 1022701-6

Downloaded From: https://www.spiedigitallibrary.org/conference-proceedings-of-spie on 26 Apr 2023 Terms of Use: https://www.spiedigitallibrary.org/terms-of-use 


\title{
Conference Committee
}

\author{
Symposium Chairs
}

Jiri Homola, Institute of Photonics and Electronics of the ASCR, v.v.i. (Czech Republic)

Bedrich Rus, Institute of Physics of the ASCR, v.v.i. (Czech Republic)

Chris Edwards, Central Laser Facility, Science and Technology Facilities Council (United Kingdom)

Mike Dunne, SLAC National Accelerator Laboratory (United States) and Linac Coherent Light Source (United States)

Ivo Rendina, Istituto per la Microelettronica e Microsistemi, CNR (Italy)

\section{Conference Chairs}

Vladimír Kuzmiak, Institute of Photonics and Electronics of the ASCR, v.v.i. (Czech Republic)

Peter Markos, Univerzita Komenského v Bratislave (Slovakia)

Tomasz Szoplik, University of Warsaw (Poland)

Conference Programme Committee

Che Ting Chan, Hong Kong University of Science and Technology (Hong Kong, China)

Jirí Čtyroký, Institute of Photonics and Electronics of the ASCR, v.v.i. (Czech Republic)

Nigel P. Johnson, University of Glasgow (United Kingdom)

Maria Kafesaki, Foundation for Research and Technology Hellas

(Greece)

Yuri S. Kivshar, The Australian National University (Australia)

Rafal Kotynski, University of Warsaw (Poland)

Andrei V. Lavrinenko, DTU Fotonik (Denmark)

Concita Sibilia, Universitá degli Studi di Roma La Sapienza (Italy)

Constantin R. Simovski, Aalto University School of Electrical

Engineering (Finland)

Costas M. Soukoulis, lowa State University (United States)

Martin Wegener, Karlsruher Institut für Technologie (Germany)

Nikolay I. Zheludev, Optoelectronics Research Center (United Kingdom)

Richard W. Ziolkowski, The University of Arizona (United States)

\section{Session Chairs}

1 Metasurfaces

Vladimír Kuzmiak, Institute of Photonics and Electronics of the ASCR, v.v.i. (Czech Republic) 
2 Metamaterials Theory

Yuri S. Kivshar, Australian National University (Australia)

3 Hyperbolic Metamaterials

Romauld Houdré, Ecole Polytechnique Federale de Lausanne

(Switzerland)

4 Metamaterials

Nigel P. Johnson, University of Glasgow (United Kingdom)

5 Plasmonics

Kestutis Staliunas, Institució Catalana de Reserca i Estudis Avançats (ICREA) (Spain)

6 Nanolasers

Baile Zhang, Nanyang Technological University (Singapore)

7 Applications of Metamaterials

Tomasz Szoplik, University of Warsaw (Poland) 